Jurnal Pendidikan Dasar, 6 (2) Desember 2018

\title{
PENERAPAN MODEL PEMBELAJARAN TAKE AND GIVE UNTUK MENINGKATKAN AKTIVITAS BELAJAR SISWA PADA MATA PELAJARAN IPA DI KELAS II SD
}

\author{
Sela ${ }^{1}$, M. Akip ${ }^{2}$, Rindah Permatasari ${ }^{3}$ \\ ${ }^{1}$ Mahasiswa Lulusan Program Studi PGSD Tahun 2018 \\ ${ }^{2.3}$ Dosen STKIP Melawi \\ Jl. RSUD Melawi km. 04 Kec. Nanga Pinoh Kab. Melawi Kalimantan Barat \\ sellavebriana@yahoo.com,m.akipstkip@id.com \\ Rindahpermatasari@gmail.com
}

\begin{abstract}
Abstrak : This study aims to improve student learning activities in science subjects in third grade elementary school. The research used is classroom action research (CAR), the procedure of this study uses PTK model Kurt Lewin. The study was carried out in two cycles, each cycle consisting of planning, acting, observing and reflecting. The results of the implementation of teaching and learning activities in the first cycle were $63.88 \%$, the second cycle was $88.57 \%$, and the increase from cycle I to cycle II was $24.69 \%$. The results of classical student learning activities in the first cycle were $64.70 \%$, the second cycle was $88.23 \%$, and the increase from cycle I to cycle II was $23.53 \%$.
\end{abstract}

Keywords: Learning Activities Students, Take and Give Learning Models, Science Learning

\begin{abstract}
Abstrak: : Penelitian ini bertujuan untuk meningkatkan aktivitas belajar siswa pada mata pelajaran IPA di kelas III SD. Penelitian yang digunakan adalah penelitian tindakan kelas (PTK), Prosedur penelitian ini mengunakan model PTK Kurt Lewin. Penelitian dilaksanakan dalam dua siklus, setiap siklus terdiri dari perencanaan (planning), pelaksaan tindakan (acting), pengamatan (observing), dan refleksi (reflecting). Hasil keterlaksaan kegiatan belajar mengajar (KBM) pada siklus I sebesar $63.88 \%$, siklus II sebesar $88.57 \%$, dan peningkatan dari siklus I ke siklus II sebesar $24.69 \%$. Hasil aktivitas belajar siswa secara klasikal pada siklus I sebesar $64.70 \%$, siklus II sebesar $88.23 \%$, dan peningkatan dari siklus I ke siklus II sebesar 23.53\%.
\end{abstract}

Kata kunci : Aktivitas Belajar Siswa, Model Pembelajaran Take and Give, Pembelajaran IPA.

$\Lambda_{\text {yang dilakukan oleh siswa di }}^{\text {ktivitas adalah segala kegiatan }}$

dalam kelas. Selama proses belajar

berlansung, aktivitas belajar siswa sangat penting selama proses belajar berlansung, karena dengan adanya aktivitas belajar proses belajar mengajar akan menarik, apabila

93| J P D, p-I S S N : 2252 - 8156 , e - I S S N : 2579 - 3993 
pembelajaran sudah menarik maka tujuan dari pembelajaran yang diharapkan akan tercapai untuk meningkatkan aktivitas belajar siswa, guru harus memberikan kesempatan kepada siswa untuk belajar sendiri dengan tujuan untuk mendapatkan pengetahuan, pemahaman dalam pembelajaran.

Natawijaya (dalam Jurnal Pendidikan Dasar 2014: 18) mengatakan bahwa aktivitas belajar adalah segala kegiatan yang dilakukan dalam proses interaksi guru dan siswa dalam rangka mencapai tujuan belajar. Aktivitas yang dimaksudkan disini penekanannya adalah pada siswa, sebab dengan adanya aktivitas siswa dalam proses pembelajaran tercipta situasi belajar aktif. Belajar aktif adalah suatu sistem belajar mengajar yang menekankan keaktifan siswa secara fisik, mental intelektual dn emosional guna memperoleh hasil belajar berupa perpaduan antara aspek koqnitif, afektif dan psikomotor.

Ilmu pengetahuan alam (IPA) adalah usaha manusia dalam memahami alam semesta melalui suatu pengamatan yang tepat pada sasaran, mengunakan prosedur, dan bisa dijelaskan dengan penalaran sehingga mendapat suatu kesimpulan. Dengan agar siswa mampu menguasi pengetahuan tentang dirinya, makhluk hidup dan alam sekitar, dengan demikan siswa akan belajar dan senang memahami sesuatu yang berguna bagi dirinya. Menurut Sulistiyorini (dalam teori belajar dan pembelajaran 2013: 169) ada sembilan aspek yang dikembangkan dari sikap ilmiah dalam pembelajaran sains yaitu: sikap ingin tahu, ingin mendapat sesuatu yang baru, sikap kerja sama, tidak putus asa, tidak berprasangka, wawas diri, bertanggung jawab, berpikir bebas, dan kedisiplinan diri.

Peneliti melaksanakan Praktik Pengalaman Lapangan (PPL) selama kurang lebih tiga bulan yaitu terhitung dari tanggal 23 September 2017 sampai dengan 23 November 2017 di SDN 9 Tanjung Lay, jumlah murid di SDN 9 Tanjung Lay sebanyak 120 orang (Kelas I s/d VI), SDN 9 tanjung lay melaksanakan 2 kurikulum yaitu Kurikulum Tingkat Satuan Pendidikan (KTSP) 2006 dan Kurikuluk 3013 (K13). Berdasarkan pengamatan selama Peneliti melaksanakan Praktik Pengalaman Lapangan (PPL) di SDN 9 Tanjung Lay, pada dasarnya proses belajar mengajar sudah cukup maksimal, namun Peneliti merasakan proses belajar menggajar khusunya 94|JPD, p-IS S N : $2252-8156$, e - I S S N : $2579-3993$ 
pada mata pelajaran Ilmu Pengetahuan Alam (IPA), aktivitas belajar siswa sangat rendah, pernyataan ini didasarkan pada nilai hasil ujian tengah semester (UTS) Tahun Pelajaran 2016/2017 pada mata pelajaran IPA yang cukup rendah dan daya serap siswa secara klasikal masih dibawah kriteria ketuntasan minimal (KKM) yaitu 70. Secara rinci dari 17 siswa hanya 6 orang yang mendapat nilai di atas KKM. aktivitas belajar siswa dikatakan rendah karena pada saat proses belajar menggajar berlansung siswa kurang memperhatikan guru saat menjelaskan, masih banyak yang sibuk sendiri, ada yang bermain dengan teman sebangku, menggagu teman lain yang sedang belajar, berpindah- pindah tempat duduk, menggambar hal-hal yang tidak ada kaitannya dengan materi yang sedang dibahas dan keluar-masuk kelas seenaknya sehingga saat diberikan pertanyaan siswa kesulitan untuk menjawab dan proses pembelajaran berlansung menjadi tidak efektif.

Adapun terkait dengan masalah siswa tersebut Peneliti mengunakan model pembelajaran take and give untuk meningkatkan aktivitas belajar siswa pada mata pelajaran IPA materi "energi dan perubahannya" di kelas III semester II. Dengan mengunakan model pembelajaran take and give yang mengajak siswa untuk saling berbagi mengenai materi yang disampaikan oleh guru, dengan kata lain tipe ini melatih siswa terlibat secara aktif dalam menyampaikan materi yang mereka terima ke teman atau siswa yang lain secara berulang-ulang.

Seperti yang telah dijelaskan di atas, dalam penelitian ini Peneliti berupaya untuk meningkatkan aktivitas belajar siswa dengan mengunakan model pembelajaran take and give, aktivitas yang ingin di tingkatkan adalah aktivitas fisik, mental dan emosional. Dan penelitian ini menggunakan penelitian tindakan kelas (PTK), atau dikenal juga dengan Classroom Action Research (CAR).

\section{METODE PENELITIAN}

Prosedur penelitian ini menggunakan metode Penelitian Tindakan Kelas (PTK) model Kurt Lewin (dalam Ekawarna, 2013: 19) yang meliputi empat komponen pada setiap siklus, yaitu perencanaan (planning), pelaksanaan (acting), pengamatan (observing), dan refleksi (reflecting), penelitian dilaksanakan dalam II siklus, siklus I dilaksanakan dua kali pertemuan dan siklus II dilaksanakan dalam satu kali 
pertemuan. Subjek dalam penelitian ini adalah guru/peneliti dan siswa kelas III SDN 9 Tanjung Lay yang berjumlah 17 orang, yang terdiri dari 9 orang lakilaki dan 8 orang perempuan.

Alat pengumpulan data yang digunakan adalah lembar keterlaksaan RPP dan lembar aktivitas belajar siswa dengan satu orang observer yaitu guru bidang studi mata pelajaran IPA SDN 9 Tanjung Lay kelas III dan satu orang teman sejawat sebagai dokumentasi.

\section{HASIL DAN PEMBAHASAN}

\section{HASIL}

\section{Hasil Tindakan Siklus I}

1) Hasil Pengamatan KBM siklus I

Data hasil kegiatan belajar mengajar (KBM) diperoleh dari lembar keterlaksanaan RPP yang di nilai dari tiga aspek yaitu kegiatan awal, kegiatan inti, dan kegiatan akhir. Dari ketiga aspek tersebut perolehan nilai kegiatan awal pada siklus I sebesar 10 dengan persentase $62,5 \%$, kegiatan inti diperoleh nilai sebesar 25 dengan persentase $62,5 \%$, dan kegiatan akhir diperoleh nilai sebesar 8 dengan persentase $66,66 \%$. Jumlah keseluruhan perolehan sebesar 191,66\%, dengan rata-rata 63,88\%. Berdasarkan hasil tersebut pelaksanaan kegiatan pembelajaran pada siklus I belum berhasil karena belum mencapai kreteria keberhasilan yaitu minimal $85 \%$.

2) Hasil Aktivitas Belajar Siklus I

Data hasil aktivitas belajar siswa di peroleh dari lembar aktivitas, siklus I diperoleh Skor tertinggi adalah 7, dengan nilai 87,5 di peroleh dua orang siswa, dan skor yang terendah adalah 3 , dengan nilai 37,5 juga di peroleh dua orang siswa. Jumlah hasil yang diperoleh keseluruhan siswa adalah 1.175.Hal ini menunjukan aktivitas belajar siswa pada siklus I masih belum berhasil karena dari 17 siswa hanya 11 orang saja yang mendaptkan nilai baik,dan persentase keberhasilan klasikal hanya $64,70 \%$, nilai tersebut menunjukan belum tercapainya kriteria keberhasilan klasikal yaitu sebesar $\leq 85$.

\section{Hasil Tindakan Siklus II}

1) Hasil Pengamatan KBM Siklus II

Hasil KBM siklus II di peroleh nilai kegiatan awal pada siklus II sebesar 15 dengan persentase 93,75\%, kegiatan inti diperoleh nilai sebesar 39 dengan persentase $88,63 \%$, dan kegiatan akhir diperoleh nilai sebesar 10 dengan persentase $83,33 \%$. Jumlah keseluruhan perolehan sebesar $265,71 \%$, dengan rata-rata $88,57 \%$.

2) Hasil Aktivitas Belajar Siklus II

Perolehan nilai aktivitas belajar siklus II menunjukan bahwa aktivitas 
belajar siswa sudah meningkat atau sudah mencapai kriteria keberhasilan klasikal, dari 17 siswa yang hadir 14 siswa mendapat nilai di atas keriteria keberhasilan yaitu minimal 70. Ada 8 siswa yang mendapat katagori amat baik, 6 siswa mendapat katagori baik dan 3 siswa mendapat katagori cukup. Persentase keberhasilan aktivitas belajar siswa secara klasikal pada siklus II adalah 88,23\% karena 14 siswa sudah mencapai kriteria keberhasilan individu yaitu minimal 70. Hasil dari aktivitas belajar siswa pada siklus II sudah mencapai kriteria keberhasilan klasikal yaitu $\geq 85 \%$.

\section{PEMBAHASAN}

Proses pembelajaran dengan menerapkan model pembelajaran take and give yang peneliti gunakan pada siklus I pada dasarnya sudah cukup baik, akan tetapi masih ada beberapa siswa yang belum terbiasa belajar dengan mengunakan model pembelajaran dan ada yang masih belum serius dalam mengikuti proses pembelajar sehingga ada beberapa siswa yang masih mendapatkan nilai kurang baik. Dengan hasil tersebut pada siklus II peneliti lebih menjelaskan lagi baik lagi dalam mengunakan model pembelajaran take and give agar siswa terbiasa dan bisa mengikuti proses pembelajaran dengan baik, peneliti juga berusaha lebih memperhatikan siswa yang kurang serius dalam belajar agar mereka dapat mengikuti proses pembelajaran dengan baik.

Berdasarkan hasil pengamatan kegiatan belajar mengajar (KBM) yang dilakukan oleh guru bertugas sebagai observer, bahwa skor yang diberikan pengamat KBM pada siklus I yaitu : Kegiatan awal $62.5 \%$, Keggiatan inti $62.5 \%$, dan kegiatan akhir 66.66\% dengan hasil rata-rata sebesar $63.88 \%$. Dengan hasil tersebut dapat disimpulkan dalam proses pembelajaran peneliti telah dinyatakan sudah cukup baik, setelah penelitian pada siklus I kemudian peneliti lansung melakukan diskusi dengan observer guna untuk memperbaiki kekurangan yang peneliti lakukan pada siklus I. observer menyarankan pada peneliti untuk lebih memperhatikan siswa yang masih belum serius dalam menggikuti pelajaran. Hasil dari penilaian kegiatan belajar mengajar siklus II terjadi peningkatan dengan kegiatan awal 93.75\%, kegiatan inti $88.63 \%$ dan kegiatan akhir $83,33 \%$ dengan rata-rata $88.57 \%$.

Hasil dari data pengamatan lembar observasi aktivitas belajar siswa 
yang peneliti gunakan dalam KBM pada siklus I yang mendapatkan nilai amat baik sebanyak 2 orang atau $11.76 \%$, mereka mendapatkan nilai amat baik karena dari mulai proses pembelajaran sangat bersemangan dalam mengikuti pembalaran, yang mendapatkan nilai baik sebanyak 9 orang atau 52.94\%, sedangkan yang mendapatkan nilai cukup sebanyak 4 orang atau $23.53 \%$ dan yang memperoleh nilai kurang sebanyak 2 orang atau $11.76 \%$, dua orang yang mendapatkan nilai kurang karena belum termotivasi untuk mengikuti pembelajaran dengan serius, masih asik berbain dan berbicara dengan teman sebangku, dengan persentase keberhasilan klasikal 64.70\%. Pada siklus II sebelum memulai pelajaran peneliti mengatakan akan memberikan imbalan berupa hadiah bagi siswa yang serius mengikuti pelajaran dan tidak bermain, berbicara dengan teman sebangku dengan pembicaraan yang tidak ada kaitannya dengan proses pembelajaran. Dengan pemberian hadiah diharapkan siswa libih termotivasi dalam mengikuti pembelajaran, pendapat ini di dukung oleh pernyataan dari Santrock (2007) "Motivasi Ekstrinsik adalah melakukan sesuatu untuk medapatkan sesuatu yang lain. sementara itu pada siklus II siswa yang berhasil sebanyak 15 siswa sedangkan yang mendapatkan nilai cukup sebanyak 2 siswa, dengan persentase keberhasilan klasikal $88.23 \%$.

Hasil verifikasi data siklus I dan siklus II peneliti menemukan beberapa temuan yaitu pengenai perolehan nilai dari aktivitas belajar siswa dengan inisial MMM dan MJY pada siklus I mendapatkan nilai kurang dikaranakan meneraka tidak menggikuti proses pembelajaran dengan baik sedangkan siswa EAK dan VAP mendapat nilai sangat baik karena selama kegiatan pembelajaran berlansung meraka sangat antusias dan semangat mengikuti pembelajaran. Dan pada siklus II siswa MP dan $\mathrm{N}$ mendapatkan nilai sangat baik karena mengalami peningkatan yang pesat, peningkatan tersebut dikarenakan mereka menggikuti pembelajaran dengan baik mulai dari menyimak saat guru menjelaskan mencatat saat diminta untuk mencacat dan dapat menyampaikan pesan, bekerja sama dalam kelompok saat kegiataan take and give dan dapat menanggapi membuat dan menjawab pertanyaan dengan baik selama kegiatan pembelajaran. Semntara dari siklus I dan siklus II ada 5 siswa yang 
tidak mengalami peningkatan namun nilai yang didapat mencapai criteria keberhasilan individu hal tersebut dikarenakan indikator yang mereka capai berbeda-beda jika di Siklus I mereka mampu mencapai indikator dalam menyimak mencatat dan bekerjasama dalam kelompok namun dak siklus II mereka mampu mencapai indikator yang lain seperti membuat kesimpulan dan menanggapi. Hasil penelitian diatas didukung dari penelitian dari Wahyunitasari, Tri (2014), dalam skripsi yang berjudul "penerapan Cooperative Learning Tipe Take and give dengan media Grafis untuk Meningkatkat Aktivitas dan hasil belajar siswa pada pembelajaran tematik kelas IV C SD Negeri 6 Metro Pusat TP 2013/2014”. Hasil penelitian ini menunjukan, Aktivitas Siswa siklus I 1,87 katagori cukup baik, siklus II 2,61 katagori baik, dan siklus III 3,25 katagori baik. Nilai rata-rata hasil belajar afektif siklus I 2,22 persentase $29,03 \%$, siklus II 2,72 persentase $58,06 \%$, dan siklus III 3,48 persentase 80,64\%. Kognitif siklus I 63,87 persentase $35,48 \%$, siklus II 70,48 persentase $61,29 \%$, dan siklus III 83,06 persentase $80,64 \%$. Psikomotor siklus I 54,83 persentase $32,25 \%$, siklus II 65,80 persentase $64,52 \%$, dan siklus III
74,45 persaentase $83,87 \%$. Berdasarkan hasil penelitian dapat disimpulkan bahwa penerapan model cooperative learning tipe take and give dapat meningkatkan aktivitas dan hasil belajar siswa pada pembelajaran tematik kelas IV C SD Negeri 6 Metro Pusat TP 2013/2012.

Kegiatan belajar mengajar pada siklus I sampai siklus II di lihat dari lembar observasi mengalami peningkatan secara signifikan yaitu sebesar $23.53 \%$ yang menunjukan ketercapaian aktivitas belajar siswa kelas III SDN 9 Tanjung Lay. Dengan hasil tersebut peneliti memutuskan untuk tidak melanjutkan penelitian dan siklus II hanya dilakukan satu kali pertemuan saja, karena dengan peningkatan dari siklus I ke siklus II telah mencapai target yang peneliti tetapkan.

\section{SIMPULAN}

Dari hasil penelitian yang telah peneliti lakukan, peneliti menarik kesimpulan bahwa menerapkan model pembelajaran take and give dengan langkah-langkah yang tepat dalam proses pembelajaran IPA dapat meningkatkan aktivitas belajar siswa kelas III SDN 9 Tanjung Lay. Hal ini dapat dilihat dari lembar keterlaksaan kegiatan belajar mengajar pada siklus I 
nilai rata-rata yang diperoleh adalah $63.88 \%$ dan pada siklus II $88.57 \%$ jadi, peningkatan dari siklus I ke siklus II sebesar 24.69\%. sedangkan hasil aktivitas belajar siswa nilai rata-rata yang diperoleh pada siklus I adalah $64.70 \%$ sedangankan pada siklus II adalah $88.23 \%$ jadi, peningkatan dari siklus I ke siklus II sebesar 23.53\%. Dari data tersebut menunjukan bawa proses pembelajaran dengan model take and give dapat meningkatkan aktivitas belajar siswa.

\section{DAFTAR PUSTAKA}

Ason,Y. 2014. "Peningkatan Aktivitas Belajar Siswa Dalam Perkuliahan Paikologi Pendidikan Dengan Metode Kerja Kelompok” Jurnal Pendidikan Dasar, program studi pendidikan guru sekolah dasar (PGSD): STKIP Melawi, 2: 164165

Ekawarna. 2013.Penelitian Tindakan Kelas. Jakarta: Referensi.

Huda. 2014. Model-model Pengajaran dan Pembelajaran. Yogyakarta: Pustaka Pelajar.

Mulyasa, H.E. 2009. Praktik Penelitian Tindakan Kelas. Bandung : PT Remaja Rosdakarya.

Natawijaya. 2014. "Aktivitas Belajar Siswa" Jurnal Pendidikan Dasar, program studi pendidikan guru sekolah dasar (PGSD): STKIP Melawi, 2: 18

Susanto, A. 2013. Teori Belajar dan Pembelajarandi Sekolah Dasar. Jakarta : Pernadamedia Group 